\title{
THE PREPOSITIONS V AND U IN BULGARIAN (ON THE SUBJECT OF LANGUAGE DEVELOPMENT)
}

\author{
Stefka Petrova \\ Sofia University "St. Kliment Ohridsky", Sofia, Bulgaria \\ stvpetrova@abv.bg
}

\begin{abstract}
One of the relatively common mistakes in written Bulgarian is the misuse of the prepositions $V$ and $U$, the disappearance of the distinction between them, and the generalization of their semantic similarity. This is manifested primarily in the replacement of the preposition $B$ by $U$. The work analyzes fully or partially recorded examples with preposition B, and is divided into three groups: 1. Misuse; 2. Possibility for two uses; 3 . Use of preposition $B$ instead of other prepositions. The author envisages further validation of the use of preposition $B$ instead of preposition $U$.
\end{abstract}

Keywords: Preposition; Use; Replacement; Error; Disappearance of the Distinction between $B$ and $U$.

\section{ПРЕАЛОЗИТЕ В И У В БЪАГАРСКИЯ ЕЗИК (КЪМ ВЪПРОСА ЗА РАЗВИТИЕТО НА ЕЗИКА)}

\author{
Стеорка Петрова \\ СУ „Св. КАимент Охрилски“, Софоия, България
}

\begin{abstract}
Резюме: ЕАна от сравнително честите грешки в писмения български език е относно употребта на преАлог В и преА^ог У, изчезване на различието межАу тях и генерализиране на приликата им в семантично отношение. Това се проявава преАи всичко в замяната на предлог У с предлог В. В работата се анализират записани цялостно ими частично примери с преА^ог B, като се разпределят в три групи: 1. Грешна употреба; 2. Възможност за Авояка употреба; З. Употреба на преАлог В вместо Аруги преАлози. Авторката преАвижАа по-нататьшно утвържАаване на употребата на преАлог В вместо преАлог У.
\end{abstract}

КАючови Ауми: преАлог, употреба, замяна, грешка, изчезване на размичието межлу Ви У

ЕАна от сравнително честите грешки в писмения български език е относно употребта на предлог В и предлог У, изчезване на различието межАу тях и генерализиране на приликата им в семантично отношение. Това се проявава преди всичко в замяната на предлог У с предлог В. Тази замяна е налична и в устната разговорна реч, но нямам по-точни 
наблюдения върху нея, затова тук ще се спра само на писмената практика.

Известно е, че предлозите са неизменямеми по орорма непьлнозначни, полисемантични, полифункционални и пр. по значение Ауми, т.е. те нямат свое собствено лексикално значение (Pashov, 1999: р. 246), а смисьльт им се определя от контекста, от свьрзването им с пьлнозначните Ауми, с което се изразяват синтактични отношения на зависимост межау частите на изречението и словосьчетанието. И все пак всеки преАлог, порали честота на употреба и по някои вътрешни и исторически закони и прави^а, се възприема от носителите на езика с определен вил значение, наричано общо (Stoyanov (ed.), 1983: р. 414), обобщено, генерализирано, основно и пр. Това важи най-вече за кратките, елносричните преАлози. Така напр. за преАлог В основното му значение е „във вътрешността на нещо”, за предлог ЗА "предназначение за някого или нещо”, за предлог С - „Съвместимост С някого/нещо" и пр. Тук ще се спра само на Ава прел^ога - В и У, разглежАайки ги в аспекта на развитие на българския език.

В ГСБКЕ, т. 2, къАето са преАставени най-Аетайлно преАлозите, автор П. Асенова (Stoyanov (ed.), 1983: рр. 409-445), за преАлог В са посочени 15 значения. НареА с предлог НА, ЗА, АО и някои Аруги, като носите^ на пространствени и темпорални значения преА^ог В е много стабилен.

За предлог У са посочени 3 основни значения: изразяване на близост, на състояние, положение или качество и на множество, свързано с някаква особеност. За пьрвите две значения се сочи като зальлжително условие употребата на съществителни за мица, а при третото не се споменава за мица, но Авата примера са от този вил: у жените и у мъжете. Със ситни букви е посочена неправилната употреба на предлог У вместо В (пол влияние на западните говори) - у гората, у стаята, у петьк, у осем часа (с. 445), т. е. замяната на В с У, а няма забележка към предлог В или У за неправилна замяна на У с В. Това навярно е пропуск, а не реална практика в писмената реч тогава - 80те голини на миналия век, когато е писана акалемичната граматика. 


\section{I. НаблюАенията ми в писмената езикова ситуация}

СпореА мен всички писатели и преводачи, чиито книги сьм прочела през последните няколко години, Аопускат употреба на В вместо У в своите романи и преводи, макар и не повсеместно, но сравнително често. Започнах да отбелязвам тази грешка и събрах елин ма^ьк корпус. Ето какви са заключенията ми от записаните примери.

\section{1. Неправимна замяна на У с В.}

По-голям брой, преоблалаващи са случаите, когато В е употребен вместо У, т.е. налице е грешка спореА правилата на българската граматика. Във всички слеАващи примери е зальлжителна употребата на прелАог У:

^ьв^ейк посреща ГарАиън в Аома си; ^ьв^ейк посреща ГарАиън У, $о$ ом си;

...нищо провинциално в този човек; ...нищо провинциално У този човек;

... в момента в него бе остана^о малко от разумното нача^о; ... в момента У него бе останало малко от разумното нача^о;

...меланхолия, която се настани в момчетата; ...меланхолия, която се настани У момчетата;

Никога няма да открие в себе си тази сила; Никога няма $а$ а открие У себе си тази сила;

...каза той с Аостойнство, което бе възхитително в този Гол, треперещ, пребит човек; ...възхитително У този човек;

Журналистиката изгражда в човека и интуиция... Журналистиката изгражда У човека и интуиция...

Както се вижАа от посочените примери, най-много са тези със замяна на У с В при свързване с местоимението в трето лице еА. ч. - в него, в 3 ^. мн.ч. - в тях (и в Аругите мица) или със съществително собствено или нарицателно за човек. Това е естествено за хуложествената митература, болшинството от която е в трето ^ице. Напр.:

Нямаше такъв въпрос в него;

...предизвика в него кратко стенание;

....ано много хора оставят поета в тях $\Delta$ а умре с отмирането Ha...; 
...разпознах в тях...;

...извеАнъж виАя своето м^аАо аз в Акино.

Интересен и показателен е фрактьт, че попаднах на употреба на Авата предлога в изречения не само на елна страница, а послеАователно в текста, в съсеАни изречения:

У баща ми се роди огнен кАаленец;

В баща ми се ражАаше нещо ново;

...пропаст, която се роди в него.

Третия пример може $а$ в възриемем (поне аз го възприемам така) като не толкова Аразнещ, т.е. прави^но употребен, ако е откъснат от конкретния текст. Същото положение срещаме при свьрзване на предлога с наречието вьтре - вьтре в него, в мен, вьтре в себе си и вьтре у него, вьтре у мен, вътре у себе си. В-то от вьтре изглежАа оказва влияние на преАлога.

\section{2. Възможна употреба и на Авата преАлога}

Когато се свързва с глагол, означаващ вмъкване, навлизане във вьтрешност, в обект, спореА мен е възможна употреба и на Авата прел^ога. Напр.:

...историята ще се забие в нас; ...историята ще се забие у нас;

...сьмненията се просмукват в него като инорекция...;

...сьмненията се просмукват у него като индекция...;

...сякаш машината го всмука в себе си;

...сякаш машината го всмука у себе си;

Мъртва точка, която ще започне $\Delta а$ се вкоренява в него;

Мъртва точка, която ще започне да се вкоренява у него.

Но тъй като при говорене, а и при писане, човек не мисли за полробности от типа на това Аали става въпрос за навлизане във вьтрешност или не, а се стреми Аа изрази точно същността на съобщението, може да прогнозираме с голям процент вероятност преминаването на такива случай към засега неправилната замяна, т.е. към генерализиране, фосилизиране и на тази употреба, на В вместо У.

\section{3. Употреба на преллог В вместо Аруги преАлози.}

Разширяването на употребата на преАлог В е Аове^о Ао появата му вместо Аруги, най-често О, но така също и вместо С, КЪМ, ОТ и пр. и^и вместо Аиректно, без преАлог (при един друг напр.). Примери: 
...погленна котарака, който гальовно се отъркваше в Ажинсите му; ...погленна котарака, който гальовно се отъркваше О Ажинсите му;

...тьрсеха напьтствие в баща си; ...тьрсеха напьтствие ОТ баща си; ...момичето и старата жена се притискаха енна в Аруга; ...момичето и старата жена се притискаха енна О/КъМ/Ө Аруга; Той усещаше като удар с юмрук всеки еАин, който попалнеше в него; Той усещаше като удар с юмрук всеки един, който попаАнеше НА/ ВъРХУ него.;

...те се натискаха един в Аруг; ...те се натискаха елин О/ С/ КЪМ/ $\theta$ Аруг;

...усещам пулса на океана в мен; ...усещам пулса на океана ВъРХУ/ОКО^О/У мен; Софри и Агата се зяпнаха еАна ө Аруга.

Големината на корпуса ми е сравнително мальк, защото случаите, кълето е възможна такава замяна, просто не са честотни в речта. Възможно е в цяла книга $\Delta а$ не се срещне нито еАин случай с неправи^но употребен преАлог У или с неправи^но употребен преАлог В.

\section{II. Причини за замяната}

Спорел мен причината за замяна е и историческа, закономерна, и съвсем съвременна, неправилна.

1. Историческа причина наричам фокта, че преллозите са наслелство от най-старата епоха на езика - те са наслеАство от праславянски език (Georgiev, 1983: р. 56) и са морорологически неразчленими, което обуславя тяхното „запаметяване", но не и „разбиране”, „обяснение”, „логичност". Ще посоча само елин пример за ^огичност при употреба на преАлог В в испански език, срещу който в български имаме предлог C: Viajo EN coche (bus, tren) - Пътувам С кола (автобус, влак). Повече ^огика има в испански, защото ние пьтуваме вътре в колата, а не съвместно, Ао колата.

2. Съвременната причина според мен е развитието на езика, промените, които настьпват в него с годините. Аиалектната употреба на У вместо В сочи, че Авата предлога са (или са били) близки, почти илентични по смисьл, но с течение на времето и по регионална, 
Аиалектна употреба са се отАалечили, но тъй като В се е установи^ стабилно в езика и е придобил широка употреба, естествено е $а$ с се „вмъква" и в още употреби, които „принаАлежат" на У. ГАавното условие за употреба на преллог У е $а$ се свързва със съществително за лице. Ст. Георгиев конкретизира - свързва се „с определен кръг съществителни имена за Аом и семейство или Аице, като се съчетават признаци за място и притежание в енно значение" (Georgiev, 1983: р. 66). Но Анес, а и в хуложествената митература, много машини, предмети, явления и Ар. се олицетворяват, приписват им се човешки черти и става смесване, Авижение между одушевени и неодушевени предмети, при което и преАлозите В и У започват $\Delta а$ се колебаят и $\Delta а$ променят своята природа и същност.

В „Граматика на българския книжовен език, фронетика и морорология" от Ст. Стоянов, която беше основен учебник за студентифрилолози в прольлжение на десетилетия, има специално място за употреба на предлог У и на предлог В (Stoyanov, 1964: р. 425). Замяната на У с В е илюстрирана само с един пример - Книгата ти е у мене (не: в мене), но от изброените позиции на предлог У може $\Delta а$ се направи изводьт, че важи за всички посочени позиции. Профр. Стоянов посочва, че У се употребява и с местоимения, заместващи лица - у него, у нея, и не предмети, кьлето е закономерна употребата на В ᄀ- в него (в театьра), в нея (в операта). Като главен критерий за разграничаване на В и У при употреба М. Иванов, който също отбелязва смесването и заместването на У с В, сочи, че „преАлог В означава вътре, вътрешност" (Andreychin, Ivanov, and Popov, 1957: р. 131). И там с еАин пример се обръща внимание на неправилна замяна на У с В - аз ще $А$ йла у вас (а не във Bac).

\section{III. Възможно решение на проблема}

Отбелязаният случай е свидетелство за движение, разширение на употребата на преАлог В и прилобиването му на още еАно значение. ЧужАенците, които обучавах на български език, въобще не се стараеха ма разберат каква е разликата межлу двата преллога и избягваха употребата на У. По отношение на испански и английски той просто е „невъзможен”, непреводим, неговото значение се изразява по 
^ексикален пьт: у нас = в нашата къща; тетрадката ми е у Мария = Мі cuaderno lo tiene Maria (Моята тетралка я има Мария, буквален превол на испанското изречение).

СпореА мен еАва $л и$ ще успеят учителите да внушат на децата Аа правят разграничението межАу В и У при съществителни и местоимения, още повече, че те просто не обрьщат внимание на езика си (има и изключения, разбира се, деца със силен интерес към езика, но те не са много често). Най-удачно е $\Delta$ а се примирим с разширяващата се, всъщност разширилата се вече употреба на В вместо У (след като я срещаме при писатели и преводачи) и да се Аопусне Авояка употреба, а по-късно езикът сам ще реши въпроса (ако, разбира се, остане да съществува толкова Аьлго). Смея Аа твьрля, че преАлог В ще поеме орункцията на предлог У, а самият той ще се окаже в перидерията на езика, като оказионализьм.

\section{АИTEPATYPA / REFERENCES}

Andreychin, Lyubomir; Ivanov, Minko; Popov, Konstantin, (1957). Savremenen balgarski ezik. Ch. II. Uchebnik za I i II kurs na uchitelskite instituti (in Bulgarian). Publisher: Narodna prosveta, Sofia, Bulgaria, 1957 // [СБЕ 1957: Аюбомир Андрейчин, Минко Иванов, Константин Попов, Съвременен български език. Ч. II. Учебник за I и II курс на учителските институти. С., Народна просвета, 1957].

Georgiev, Stanyo, (1983). Morfologiya na savremenniya balgarski ezik (neizmenyaemi dumi) (in Bulgarian). Publisher: Nauka i izkustvo, 1983, Sofia, Bulgaria. // [Георгиев 1983: Георгиев, Станьо, Морфология на сьвременния бьлгарски език (неизменяеми Ауми). С., Наука и изкуство, 1983].

Pashov, Petar, (1999). Balgarska gramatika (in Bulgarian). Publisher: Hermes, Sofia, Bulgaria, 1999 // [Пашов 1999: Пашов, Петър, Българска граматика. С., Хермес, 1999].

Stoyanov, Stoyan, (1964). Gramatika na balgarskiya knizhoven ezik. Fonetika i morfologiya (in Bulgarian). Publisher: Nauka i izkustvo, Sofia, Bulgaria, 1964 // [Стоянов 1964: Стоянов, Стоян, Граматика на българския книжовен език. Фонетика и морорология. С., Наука и изкуство, 1964].

Stoyanov, Stoyan (editor). (1983). Gramatika na savremenniya balgarski knizhoven ezik. Volume 2: Morfologiya (in Bulgarian). Publisher: BAS - Institute for Bulgarian Language, Sofia, Bulgaria, 1983, р. 1276 // [ГСБКЕ 2 1983: Граматика на съвременния български книжовен език. Т. 2. Морфоология. С., БАН, 1983]. 


\section{КУАТУРНО-ИСТОРИЧЕСКО НАСАЕАСТВО: \\ ОПАЗВАНЕ, ПРЕАСТАВЯНЕ, АИГИТААИЗАЦИЯ}

\section{CULTURAL AND \\ HISTORICAL \\ HERITAGE}

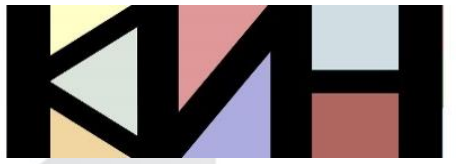

PRESERVATION PRESENTATION DIGITIZATION
Материалите в сборника са обект на авторско право. Разрешава се безвъзмезАното ползване на техни електронни/ хартиени копия само за лична употреба или обучение, при пь^но цитиране на текущата страница и слеА писмена декларация от цитиращия за Аипса на търговски намерения. За копиране пол Аруга фрорма, препубликуване или публикуване на сървъри се изисква писмено разрешение и/или заплащане.

() Авторски колектив, 2020 Техническо реАактори: Николай Ноев Калина Сотирова-Вълкова
This work is subject to copyright. Open and free of charge use of digital/hard copies of publications is granted only for personal or educational use, with full citation of the current page, and after written declaration of the quoting side for not-commercial Intention. For any other reproducing types, republishing, photocopying, recording, or any other storage retrieval system/ server written permission and/or fee is required.

(C) Authors` Group, 2020

Technical editors:

Nikolay Noev

Kalina Sotirova-Valkova

\section{Научна пореАица: том 6, брой 1 (8)/2020 Science series: vol. 6 , issue $1(8) / 2020$}

